\title{
Frequency regulation with vehicle-to-grid (V2G) option in multi-generation power network
}

\author{
Hitesh Dutt Mathur, \\ Yogesh Krishan Bhateshvar \\ Birla Institute of Technology and Science, \\ Pilani, Vidhya Vihar, \\ Pilani, 333031, India \\ E-mail: mathurhd@pilani.bits-pilani.ac.in; \\ yogeshbhateshvar@gmail.com
}

In a smart grid scenario, penetration of large scale renewable energy sources is increasing rapidly. Even at global level, serious discussions are being done to reduce carbon emission. In order to achieve this goal of cleaner and greener environment for newer generations, fossil fuel based vehicles are being replaced with electric vehicles. This concept of having more electric vehicles will not only control pollution level but also supply electrical power back to the grid when have surplus power stored. It is going to be a win-win situation for both consumers and the grid. The concept termed as Vehicle-to-Grid (V2G) is explored for frequency regulation aspect in a multi-generation power network in this paper. When established automatic generation control (AGC) in interconnected power system is not sufficient to manage balance between demand and supply, vehicle energy storage is considered a viable option for a shortterm active power support in order to bring frequency back to normal. In energy storage possibilities, super conducting magnetic energy storage, ultra-capacitor, etc. are primarily discussed. This paper focuses on an integrated model of vehicle-to-grid (V2G) and wind power as alternatives to supply instant power to regulate frequency when the system is subjected to sudden perturbation. APSO (adaptive particle swarm optimization) optimized fuzzy logic controller is used to intelligently suppress frequency and tie-line power oscillations. Results obtained are comprehensively presented and discussed in achieving power-frequency balance. MATLAB/Simulink is used for the simulation purpose.

Key words: automatic generation control, adaptive particle swarm optimization,vehicle-to-grid, short-term active power, wind power, fuzzy logic controller

\section{INTRODUCTION}

Recently, there has been substantial increase in penetration of renewable sources of energy into the electrical grid. The governments of most of the countries worldwide are encouraging the use of clean and green power in their countries by means of supporting various smart grid projects. This has given impetus to researchers across the globe to give a serious thought to implement a viable solution for reduction in greenhouse gases which are caused by emission of conventional thermal plants and existing vehicles. Policy makers are promoting the use of electric vehicles (EVs) with an option for 
user to sell electrical power to the grid and get benefitted in different means.

According to statistics available, EVs are in idle situation in $90 \%$ of the time every day and have sufficient energy to cater to ancillary service requirements, particularly frequency regulation in a large power system [1-3]. There have been advanced battery technologies and charging infrastructure which is leading to greater use of plugged-in hybrid electric vehicles (PHEVs) and EVs in near future. Therefore, V2G is seen as a potential source in frequency regulation [4-7]. Reference [8] has used EVs for secondary frequency modulation and results in decrease in area control error and tie-line deviations. In the US, China and India, there are expectations of a large number of EVs on the road as per their government plans [9-12]. Moreover, PHEVs are also being looked at as a controllable load for a future smart grid $[13,14]$. PHEV sare basically charged in the night period as electricity price is cheap during that time [15]. An autonomous distributed V2G control of grid-connected PHEVs and EVs to the actual frequency measurements in Eastern $50 \mathrm{~Hz}$ system and Western $60 \mathrm{~Hz}$ system of Japan is proposed in [16]. Reference [17] proposes the V2G control based on the average battery State of Charge (SOC) deviation control applied to compensate the AGC capacity in the system. Reference [18] concentrates on the autonomous distributed V2G control considering the charging request and battery condition for suppressing the fluctuations of frequency and tie-line power flow in the two-area interconnected power system. The battery SOC is controlled by the SOC balance method. There has been various control strategies implemented in a multi-area power system by researchers from conventional control to intelligent control [19-23].

This paper is mainly focusing on understanding the impact of $\mathrm{V} 2 \mathrm{G}$ and wind power generating system with inertial support mechanism (WPGS) in a two-area interconnected power system on the maintenance of power-frequency balance. EVs are considered in this paper a sufficiently large energy storage which will cater to the power grid when there is need of power in case of sudden rise in demand. Wind power has gained sufficient popularity amongst power generating companies. Apart from supplying electrical power to the grid, wind generators are also used to provide inertial support during large and sudden load perturbation. The modelling of V2G and WPGS is done in Section II of the paper. Controller design is another important aspect presented in the paper. Different intelligent techniques are used in literature for approaching this power system power-frequency balance issue. A fuzzy logic controller with genetic algorithm for optimization is used. The model and strategy are discussed in detail in Section III. Section IV presents the simulation results and discussion on different conditions of V2G and wind power connection in the power system. Conclusions are presented in Section V.

\section{SYSTEM MODELLING}

\section{Mathematical modelling of two-area power system}

The interconnected power system considered has two control areas each having thermal units. Areas are connected via tie-line for exchange of power. The system parameters are the same as used in [20] for thermal units. In automatic generation control (AGC), the difference between actual generation and scheduled generation is termed as area control error (ACE) for an interconnected power system:

$$
\mathrm{ACE}_{i}=\Delta P_{\text {tie }}+b_{i} \Delta f
$$

where $b_{i}$ is frequency bias constant, $\Delta f$ is frequency deviation, and $\Delta P_{\text {tie }}$ is change in tie-line power.

So, the scheduled tie-line power flow between area- 1 and area- 2 is:

$$
\Delta P_{\text {tiel2, sch }}=\Delta P_{\mathrm{L}, \mathrm{A} 1 \rightarrow \mathrm{A} 2}-\Delta P_{\mathrm{L}, \mathrm{A} 2 \rightarrow \mathrm{A} 1}
$$

The scheduled tie-line power flow between area- $i$ and area- $j$ can be represented in (3):

$$
\Delta P_{\text {tieij; sch }}=\Delta P_{\mathrm{L}, A i \rightarrow A j}-\Delta P_{\mathrm{L}, A j \rightarrow A i}
$$

Figure 1 presents the block diagram for a two-area power system with integrated V2G and WPGS, in which both controls have thermal based generation units. 


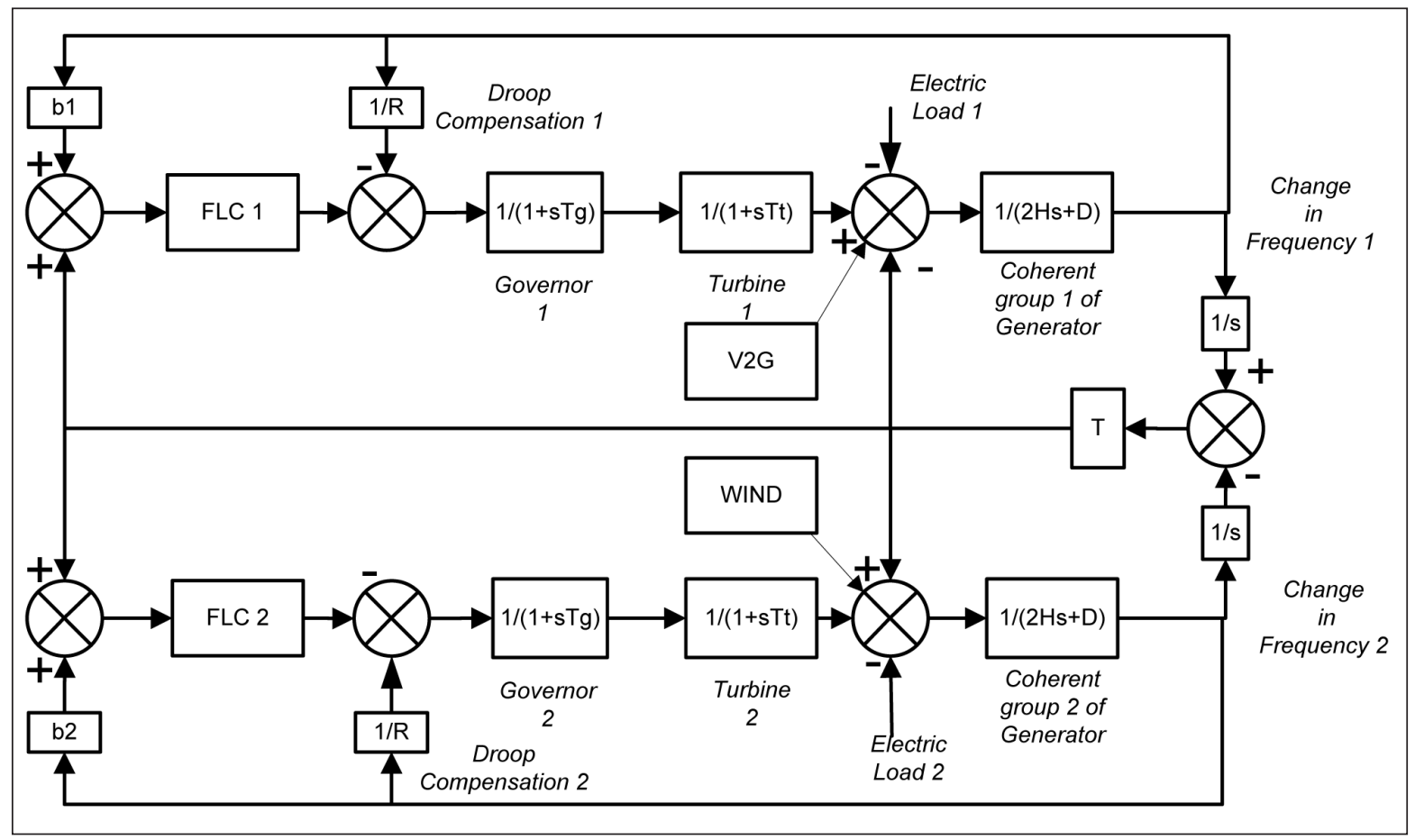

Fig. 1. Block diagram for two-area power system with integrated vehicle-to-grid (V2G) and wind power generating system (WPGS)

\section{Mathematical modelling of wind power}

\section{generating system}

All areas in the developed restructured power system model are connected with a wind power generating unit separately. A Doubly-fed Induction Generator based WIND model [25] is used for the inertial support to have short-term active power supply, as shown in Fig. 1. A one-mass model for the mechanical drive of the turbine is considered. The mechanical power developed by the turbine is given as:

$$
P_{M}=\frac{1}{2} \rho \pi R^{2} C_{p}(\lambda, \beta) v^{2},
$$

where $R$ is the rotor radius, $v$ is the wind speed, $\rho$ is the air density, and $C_{p}$ is the power coefficient of the turbine which depends on the pitch angle, $\beta$, and the tip-speed ratio, which is defined by:

$$
\lambda=\frac{R \omega_{e}}{v},
$$

where $\omega_{e}$ is the rotor speed. The power coefficient is a characteristic of the wind turbine, and for our case, it can be approximated by

$$
C \downarrow p(\lambda, \beta)=\Sigma_{\downarrow}(i=0)^{\uparrow} 4 \Sigma_{\downarrow}(j=0)^{\uparrow} 4
$$

$$
C_{p}(\lambda, \beta)=\Sigma_{i=0}^{4} \Sigma_{j=0}^{4} \alpha_{i, j} \beta^{i} \lambda^{j},
$$

where, $\alpha_{i, j}$ is coefficient and $\beta^{i}$ is pitch angle. The rotor speed, as well as the pitch angle must be controlled to optimize the amount of power captured by the wind turbine. Thus, a reference speed, $\omega^{\rightarrow}$ is generated based on the electric power, $P_{e}$, for maximum power tracking and given by (7):

$$
\omega^{\rightarrow}=-0.67 P_{e}^{2}+1.42 P_{e}+0.51 .
$$

Then, the generator speed is controlled by a Proportional-Integral (PI) controller that has as output the value $P_{\omega} \rightarrow$ given by:

$$
P_{\omega} \rightarrow=K_{P}\left(\omega \rightarrow-\omega_{e}\right)+K_{I} \int\left(\omega^{\rightarrow}-\omega_{e}\right) d t,
$$

where, $K_{P}$ and $K_{I}$ are proportional and integral gains. To support the frequency variation in the grid, the so-called inertial control must be added to the system. This controller adds to the power reference output signal given by:

$$
P_{f}^{\rightarrow}=-K_{d f} \frac{d \Delta f}{d t}-K_{p f} \Delta f,
$$


where $K_{d f}$ and $K_{p f}$ are constants and must be chosen as weights to the frequency deviation derivative and frequency deviation, respectively. This signal can increment the system inertia, supporting the frequency variation indirectly.

Thus, the total active power reference for our turbine must be calculated as follows:

$$
P_{f \omega}^{\rightarrow}=P_{\omega}^{\rightarrow}+P_{f}^{\rightarrow}
$$

The penetration level is possible to change for study and variation is studied extensively in [20] but it is considered to be $30 \%$ for all simulation purposes in this paper.

\section{Mathematical modelling of vehicle-to-grid (V2G) system for frequency regulation}

The EVs participation in AGC from a broader perspective is used in developing a mathematical model of EVs. Secondary frequency regulation is primarily accomplished by control action with area control error as input to controller. EVs for vehicle-to-grid process need to be modelled by keeping in view of change in frequency and AGC control signal. Communication channels between AGC and EVs are simplified and designed as an aggregated EVs model for secondary frequency control. The State of Charge (SOC) of electric vehicles is noted at every instant to have the correct accumulated capacity of all available EVs for frequency regulation. Therefore, EVs are basically used as reserve capacity to cater at the time of sudden demand in power system, and this would be the case in peak hours during a load cycle. The inputs are controller output and change in frequency to the aggregated model of EVs for V2G as shown in Fig. 2.

The prime purpose of having EVs grouped together is that they represent a virtual large energy storage plant with a sufficient capacity to support AGC at the time of peak demand or sudden demand during the course of power supply at any other time.

\section{PROPOSED CONTROL STRATEGY}

In this paper, an optimized control strategy has been implemented. An optimized fuzzy logic controller, where scaling parameters are optimized using adaptive particle swarm optimization (APSO) has been used. The perturbations are represented by the demand raised from various electrical loads connected. In the recent times, a fuzzy logic controller (FLC) has gained popularity in control system applications in uncertain and nonlinear systems. In a complex and multi-variable power system, conventional control methods may not give satisfactory solutions. On the other hand, FLCs are more robust and more reliable in solving a wide range of control problems. Fuzzy logic is a systematic and easier way to implement control algorithm for uncertain and indefinite models in engineering. The FLC modelling consists of three steps as fuzzification, formation of fuzzy control rule base, and defuzzification [23]. The control actions of a FLC are described by some set of linguistic rules and these are obtained from experience or trial and error, but this way does not lead towards optimum results. In order to achieve optimized results, a FLC is done using a powerful optimization tool.

Seven membership functions (MFs) have been used to explore the best performance as shown in Fig. 4. The FLC is designed based on a multiple input and single output type structure. The first input is $\mathrm{ACE}_{i}$ and the other one is derivative of $\mathrm{ACEi}\left(\frac{d \mathrm{ACE}_{i}}{d t}\right)$. In Fig. 3, $K_{e}$ and $K_{c e}$ are scaling factors for both input variables, respectively, and $K_{p}$ and $K_{i}$ are the proportional and integral gains, whereas $U_{i}$ is a crisp value and $u_{i}$ is a control signal for the system:

$$
u_{i}=-K_{p} U_{i}-K_{i} \int U_{i} d t
$$

Initially for each variable, MF's distributions are kept the same. The MF specifies the degree to which a given input belongs to a set or a function

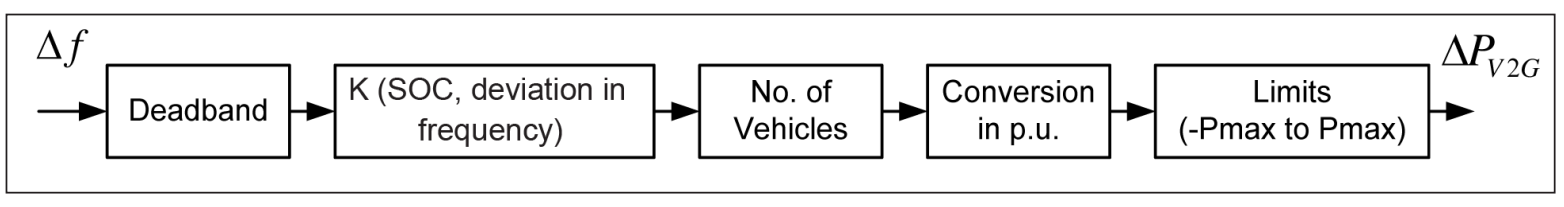

Fig. 2. Vehicle-to-grid (V2G) for AGC 


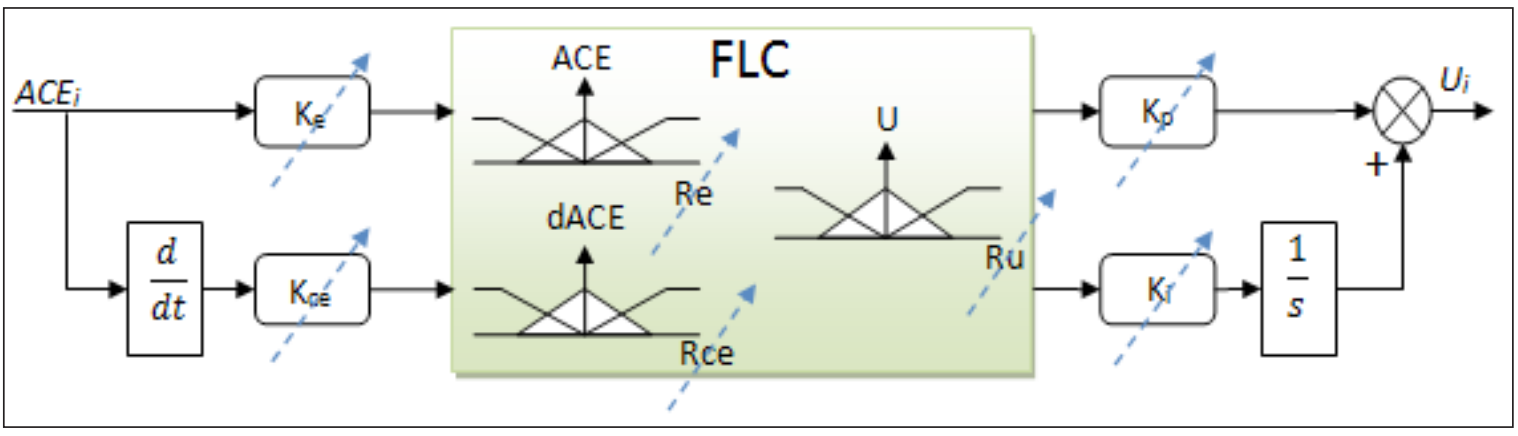

Fig. 3. MISO fuzzy logic controller

that defines how each point in the input space is mapped to a degree of membership between 0 and 1. MF's distribution for ACE1 is within [-0.5], dACE1 is within [-0.1], and U1 is within [-0.5] for FLC controller for area-1, and for area-2 MF's distribution for ACE2 is within [-0.5], dACE2 is within $[-0.1]$, and $\mathrm{U} 2$ is within [-0.1] for FLC controller for area-2.

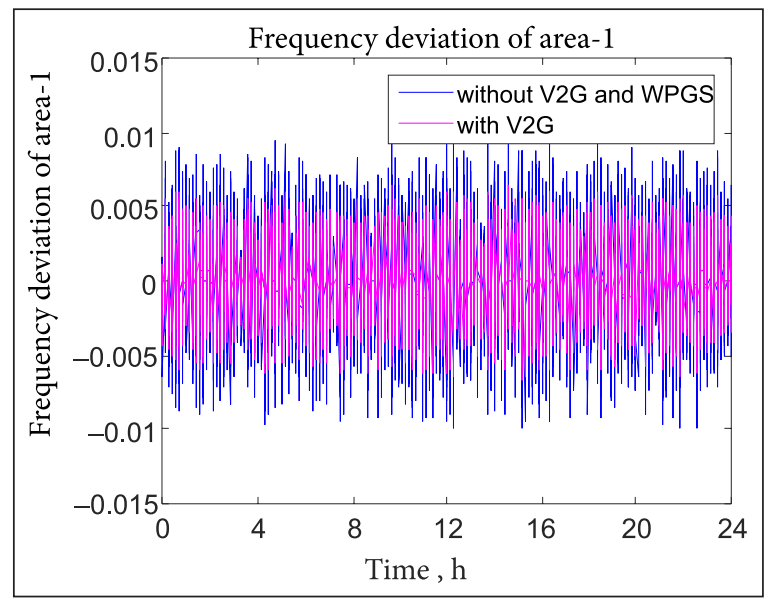

Fig. 4a. Frequency of deviation of area-1 with only V2G

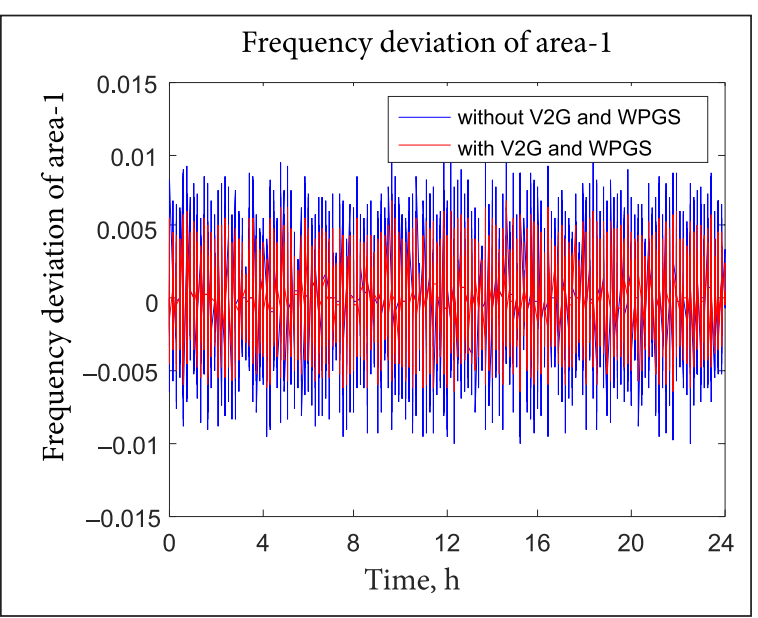

\section{SIMULATIONS AND DISCUSSION}

Simulations are performed on a two-area model to analyse the impact of V2G and WPGS in different cases. The cases are compared with the basic condition of deviation in both areas without V2G and WPGS. Case 1 results are shown in Fig. $4 \mathrm{a}-\mathrm{c}$ where frequency deviation in

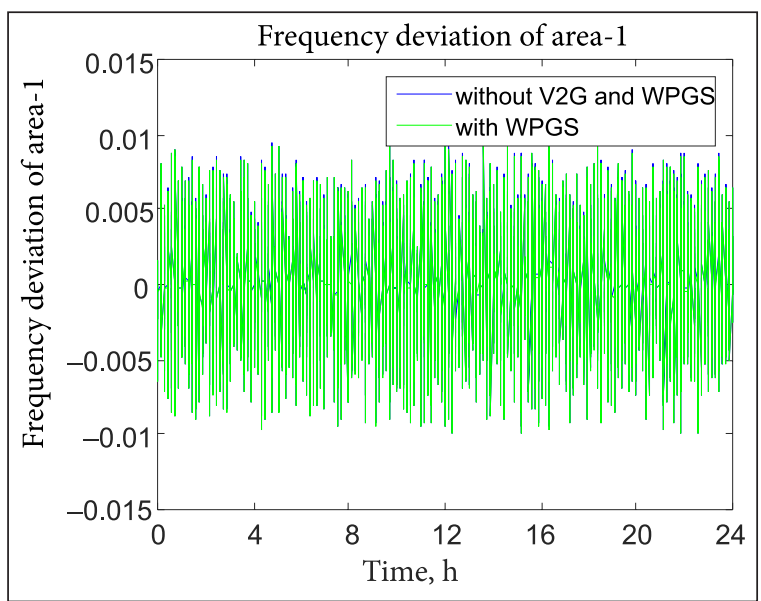

Fig. 4b. Frequency of deviation of area-1 with only WPGS

Fig. 4c. Frequency of deviation of area- 1 with both V2G and WPGS 


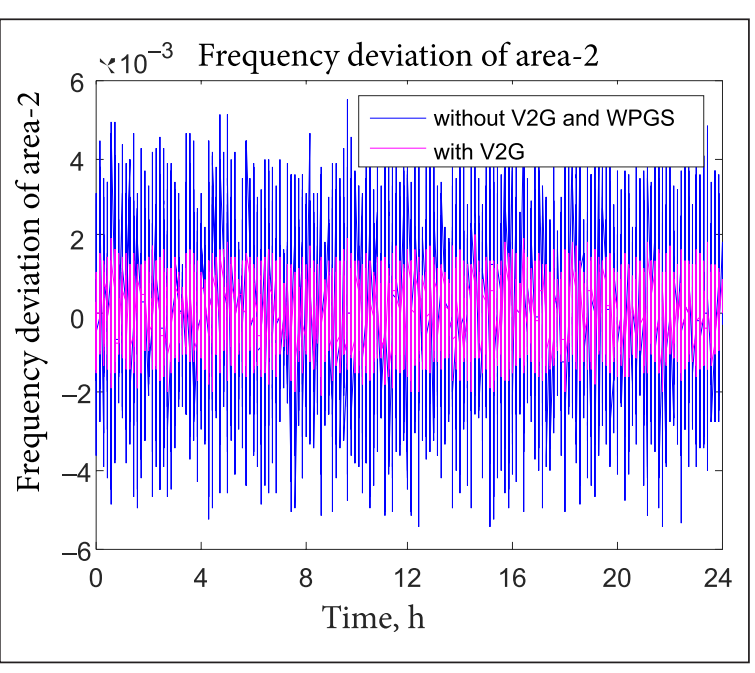

Fig. 5a. Frequency of deviation of area-2 with only V2G

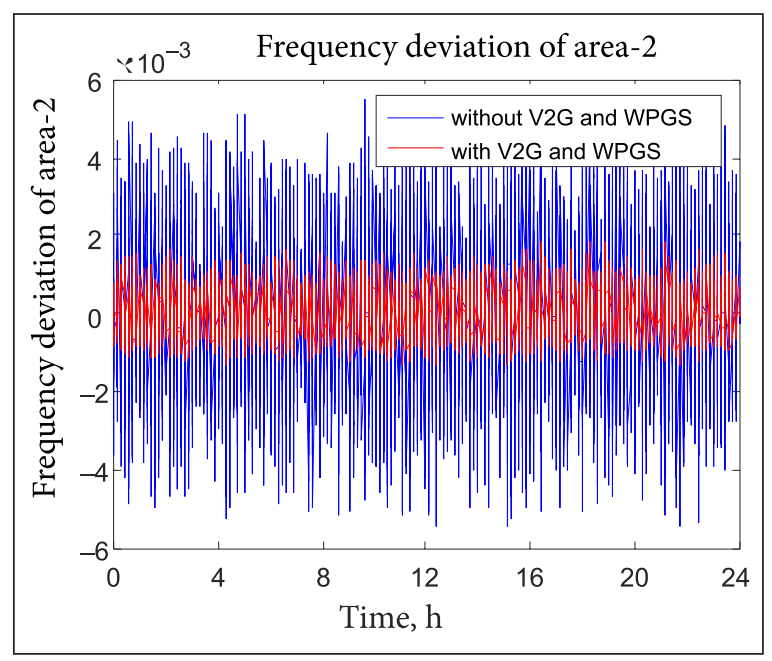

Fig. 5c. Frequency of deviation of area-2 with both V2G and WPGS

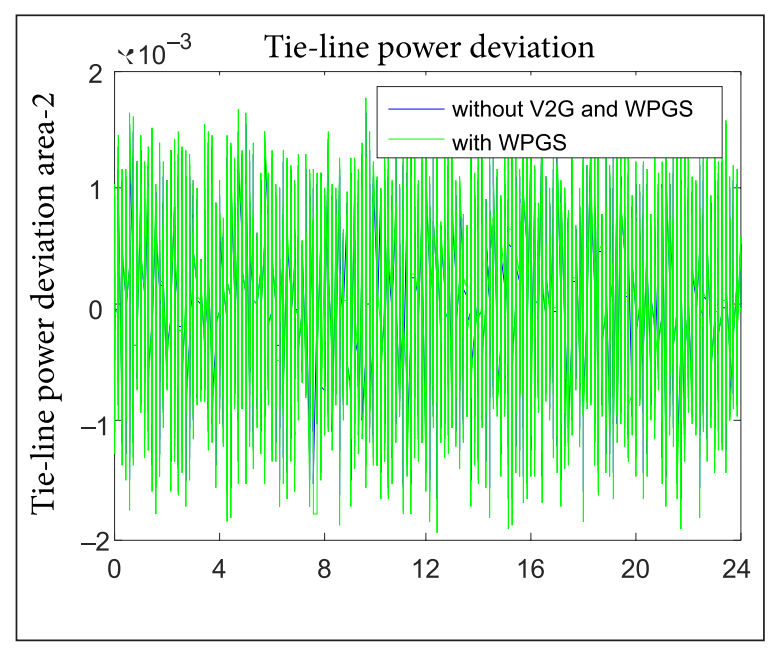

Fig. 6b. Tie-line power deviation with only WPGS

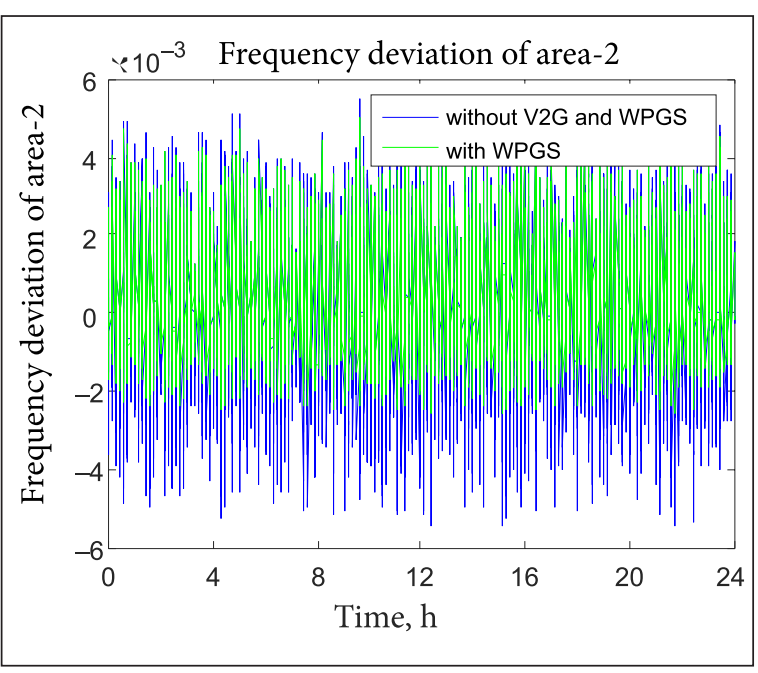

Fig. 5b. Frequency of deviation of area-2 with only WPGS

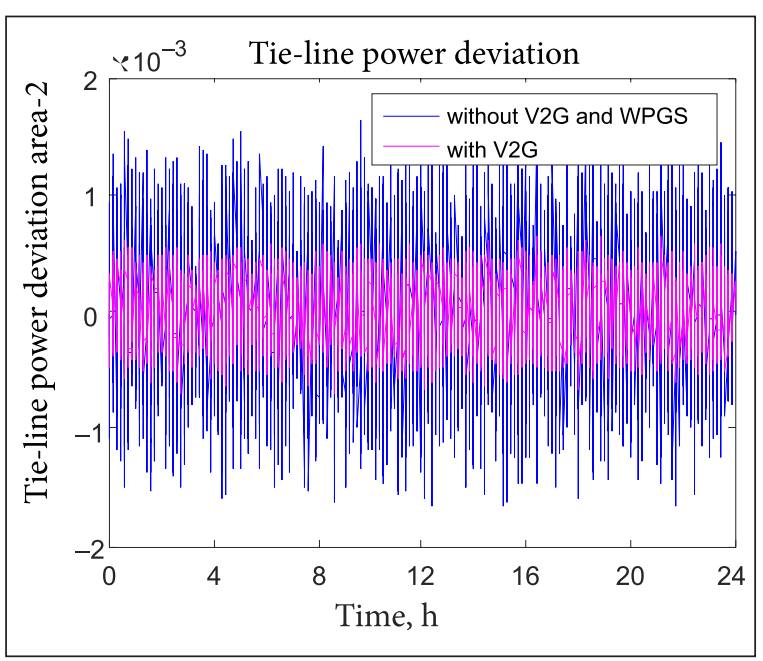

Fig. 6a. Tie-line power deviation with only V2G

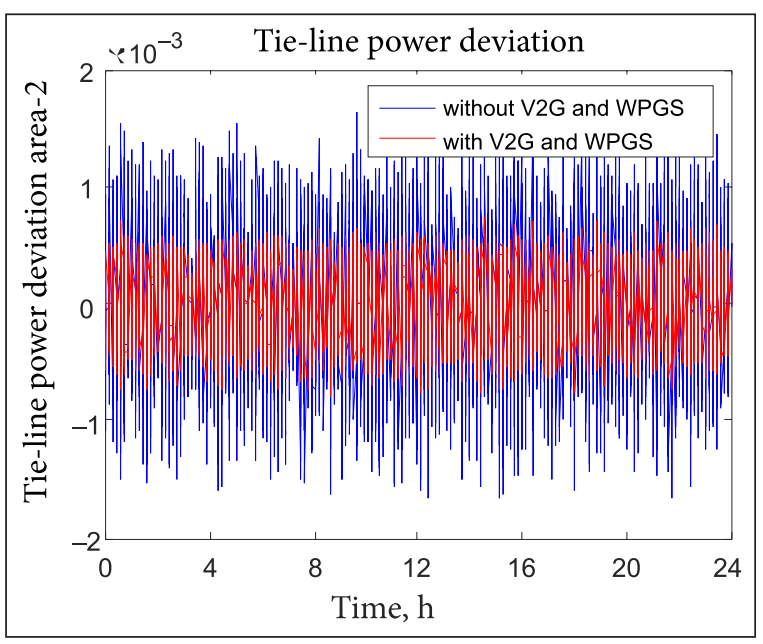

Fig. 6c. Tie-line power deviation with both V2G and WPGS 
area-1 with V2G, with WPGS, and both are represented, respectively. Results obtained are using MATLAB/Simulink. Similar cases are simulated to observe deviation in area- 2 and Tie-line power flow as presented in Fig. $5 \mathrm{a}-\mathrm{c}$ and Fig. 6a-c, respectively.

From these Figures, it is observed that AGC with V2G and WPGS is an effective technique for oscillation suppression. Figure 7 shows SOC of

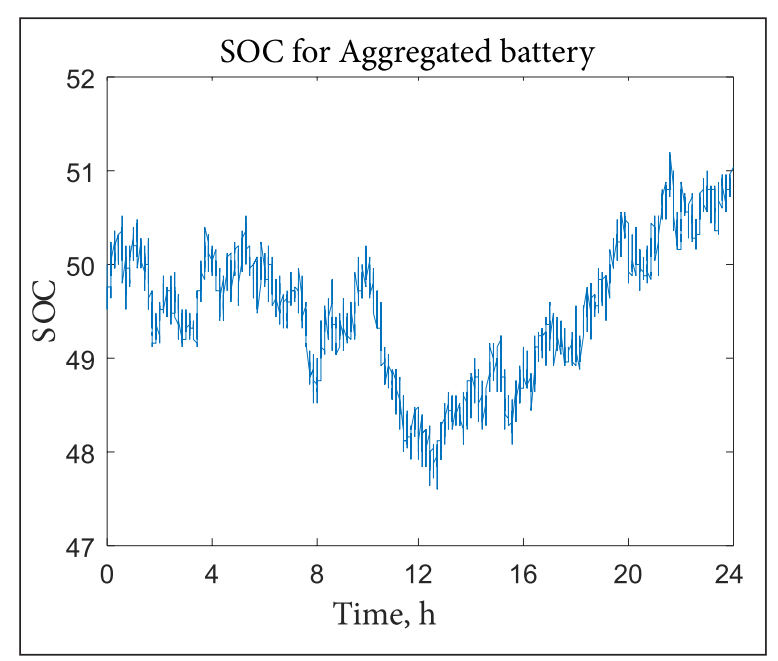

Fig. 7. SOC of aggregated battery

aggregated battery utilized for V2G. It shows that battery energy is utilized as PV2G for balancing the mismatch between demand and supply. In Fig. 8 and Fig. 9, PV2G and WPGS are shown

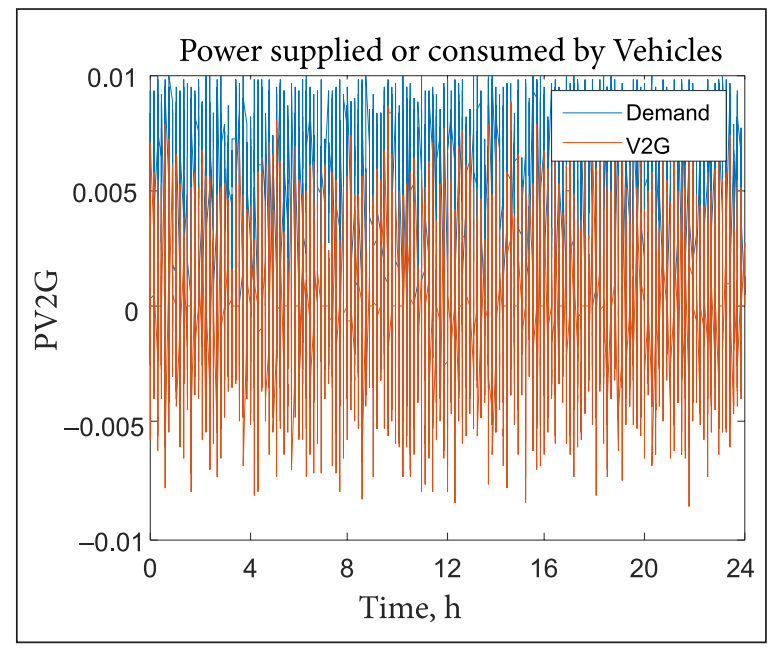

Fig. 8. Power supplied or consumed by V2G with respect to power demand

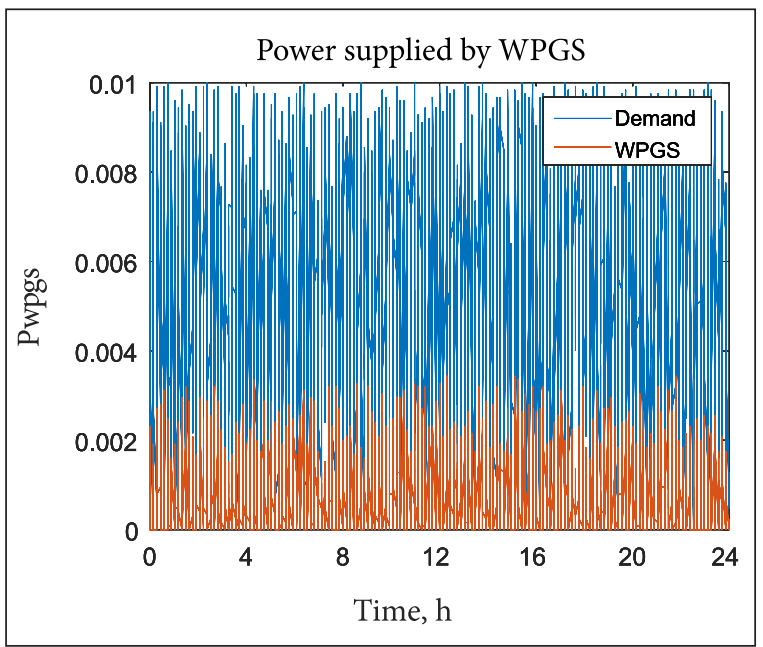

Fig. 9. Power supplied by WPGS with respect to power demand

with respect to continuously varying demand. The controller is optimized with the integral of absolute error (IAE) as an objective function. The values obtained for the objective function in all four cases are presented in Table. It is clearly evident that both together will have a significant impact on oscillation suppression of change in frequency in both areas and tie-line power. The WPGS alone may not be sufficient as it only supports the overall inertia of power system when sudden change in demand arises but V2G can act faster as compared to any other means as its time constant is less than existing mechanical components which are used to bring frequency back to normal.

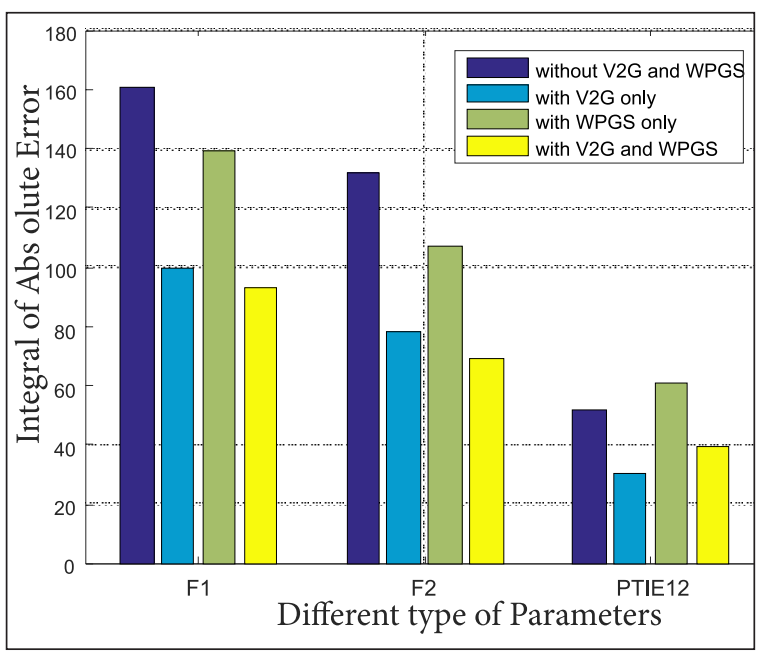

Fig. 10. IAE for different cases for devation in frequency of arae-1 and area-2 and for deviation in tie-line power 
Ta ble. IAE values for different cases for deviation in frequency of arae- 1 and area- 2 and for deviation in tie-line power

\begin{tabular}{cccccc}
\hline & Without V2G and WPGS & With V2G only & With WPGS only & With WPGS and V2G \\
\hline $\boldsymbol{\Delta} \boldsymbol{f}_{\mathbf{1}}$ & 160.6958 & 99.4908 & 139.1545 & 93.4408 \\
\hline $\boldsymbol{\Delta} \boldsymbol{f}_{\mathbf{2}}$ & 131.5306 & 78.5517 & 107.1213 & 69.5696 \\
\hline $\boldsymbol{\Delta}$ tie $_{\mathbf{1 2}}$ & 51.7766 & 30.4421 & 60.8662 & 39.2219 \\
\hline
\end{tabular}

\section{CONCLUSIONS}

An integrated V2G and WPGUs model is presented in the paper for automatic generation control in a two-area interconnected power system. A newly developed V2G model represents an aggregated V2G where vehicles are assumed to be available for bulk power supply for a short term. This is justified and validated with simulation results presented. Power system engineers come across the situations of sudden rise in demand quite often. This solution is a win-win situation for both customers and power companies. Two different models of power system are used for a comprehensive analysis of the effect of wind power and $\mathrm{V} 2 \mathrm{G}$ power. Wind power generating units are modelled with inertial support which is crucial at the time of sudden load requirement in the power system because thermal and hydro generators lose their kinetic energy to support additional demand which is undesirable. Despite the fact that an associated power management system will have to be quick in transferring information through secured and robust communication channels, V2G has capability of changing power scene in days to come.

Received 5 April 2016 Accepted 15 May 2016

\section{References}

1. Baccino F., Marinelli M., Massucco S., Silvestro F. Low voltage microgrid under islanded operation: Control strategies and experimental tests. 8th Mediterranean Conference on Power Generation, Transmission, Distribution and Energy Conversion (MEDPOWER 2012), 1-3 Oct. 2012, Cagliari. P. 1-7.

2. Zoka Y., Tonoda R., Mashima Y., Sasaki Y., Yorino N. An on-demand control system for demand and supply control of small independent power grids. 47th International Universities Power Engineering Conference (UPEC), 4-7 Sep. 2012, London. P. 1-6.

3. Tian W., He J., Niu L., Zhang W., Wang X., Bo Z. Simulation of vehicle-to-grid (V2G) on power system frequency control. Innovative Smart Grid Technologies - Asia (ISGT Asia), IEEE, 21-24 May 2012. P. 1-3.

4. Ota Y., Taniguchi H., Nakajima T., Liyanage K. M., Baba J., Yokoyama A. Autonomous distributed V2G (vehicle-to-grid) considering charging request and battery condition. Innovative Smart Grid Technologies Conference Europe (ISGT Europe), IEEE PES, 11-13 Oct. 2010. P. 1-6.

5. Shimizu K., Masuta T., Ota Y., Yokoyama A. Load frequency control in power system using vehicle-to-grid system considering the customer convenience of electric vehicles. Proc. International Conference on Power System Technology (PowerCon), 24-28 Oct. 2010, Hangzhou. P. 1-8.

6. Liyanage K. M., Yokoyama A., Ota Y., Nakajima T., Taniguchi H. Impacts of communication delay on the performance of a control scheme to minimize power fluctuations introduced by renewable generation under varying V2G vehicle pool size. Smart Grid Communications (SmartGridComm), 2010, Gaithersburg, MD. P. 85-90.

7. Brooks A., Lu E., Reicher D., Spirakis C., Weihl B. Demand dispatch. IEEE Power \& Engineering Magazine. 2010. Vol. 8. Issue. 3. P. 20-29.

8. Almeida P. M. R., Lopes J. A. P., Soares F. J., Vasconcelos M. H. Automatic Generation Control operation with electric vehicles. Bulk Power System Dynamics and Control (iREP) - VIII (iREP), 2010 iREP Symposium, 1-6 Aug. 2010. P. 1-7.

9. Su W., Chow M.-Y. Performance evaluation of an EDA-based large-scale plug-in hybrid electric vehicle charging algorithm. IEEE Trans. Smart Grid. 2012. Vol. 3(1). P. 308-315.

10. Cao Y., Tang S., Li C., Zhang P., Tan Y., Zhang Z., Li J. An optimized EV charging model 
considering TOU price and SOC curve. IEEE Trans. Smart Grid. 2012. Vol. 3(1). P. 388-393.

11. Ministry of Power, Government of India. Smart Grid Vision and Roadmap for India. 12 August 2013.

12. Vachirasricirikul S., Ngamroo I. Robust LFC in a smart grid with wind power penetration by coordinated V2G control and frequency controller. IEEE Trans. Smart Grid. 2014. Vol. 5. No. 1. P. 371-380.

13. Yokoyama A. Smarter grid I. IEEJ J. 2010. Vol. 30(2). P. 94-97.

14. Yokoyama A. Smarter grid II. IEEJ J. 2010. Vol. 30(3). P. 163-167.

15. Takagi M., Yamaji K., Yamamoto H. Power system stabilization by charging power management of plug-in hybrid electric vehicles with LFC signal. Proc. 2009 IEEE Veh. Power Propulsion Conf. P. 822-826.

16. Ota Y., Taniguchi H., Nakajima T., Liyanage K. M., Yokoyama A. An autonomous distributed vehicle-to-grid control of grid-connected electric vehicle. Proc. 2009 IEEE Ind. Inf. Syst. Conf. P. 414-418.

17. Masuta T., Yokoyama A. Supplementary load frequency control by use of a number of both electric vehicles and heat pump water heaters. IEEE Trans. Smart Grid. 2012. Vol. 3(3). P. 1253-1262.

18. Ota Y., Taniguchi H., Nakajima T., Liyanage K. M., Baba J., Yokoyama A. Autonomous distributed V2G (vehicle-to-grid) satisfying scheduled charging. IEEE Trans. Smart Grid. 2012. Vol. 3(1). P. 559-564.
19. Bhateshvar Y. K., Mathur H. D., Siguerdidjane H., Bhanot S. Frequency stabilization for multi-area thermal-hydro power system using genetic algorithm-optimized fuzzy logic controller in deregulated environment. Electric Power Components and Systems. 2015. Vol. 43(2). P. 146-156.

20. Bhateshvar Y. K., Mathur H. D., Siguerdidjane H. Study of impact of wind power generating system integration on frequency stabilization in multi-area power system with fuzzy logic controller in deregulated environment. Frontiers in Energy. 2015. Vol. 9(1). P. 7-21.

21. Bhatt P., Roy R., Ghoshal S. P. Optimized multi area AGC simulation in restructured power systems. Int. J. Elect. Power Energy Syst. 2010. Vol. 32(4). P. 311-322.

22. Panda S., Yegireddy N. K. Automatic generation control of multi-area power system using multi-objective non-dominated sorting genetic algorithm-II. Int. J. Elect. Power Energy Syst. 2013. Vol. 53. P. 54-63.

23. Çam E., Kocaarslan I. Load frequency control in two area power systems using fuzzy logic controller. Energy Convers. Manag. 2005. Vol. 46(2). P. 233-243.

24. Tan W., Zhang H., Yu M. Decentralized load frequency control in deregulated environments. International Journal of Electrical Power \& Energy Systems. 2012. Vol. 41(1). P. 16-26.

25. Boukhezzar B., Siguerdidjane H. Nonlinear control with wind estimation of a DFIG variable speed wind turbine for power capture optimization. Energy Conversion and Management. 2009. Vol. 50(4). P. 885-892. 
Hitesh Dutt Mathur, Yogesh Krishan Bhateshvar

ELEKTROMOBILIO DARBO İ TINKLĄ

ALTERNATYVA DAŽNIUI REGULIUOTI DAUGIAGENERATORINĖJE ELEKTROS SISTEMOJE

\section{Santrauka}

Išmaniųjų tinklų plètros scenarijuose numatomas spartus ir platus atsinaujinančius išteklius naudojančios generacijos augimas. Indèlị ị švaresnès ir žalesnès aplinkos kūrimą būsimoms kartoms gali įnešti ir organinius degalus naudojančių automobilių keitimas elektromobiliais. Be to, elektromobiliai gali grąžinti i tinklą sukauptos energijos perteklių. Tai abipusiškai naudinga ir pačiam tinklui, ir vartotojams. Straipsnyje tiriama, kaip tokią elektromobilio ir elektros tinklo sąsają (angl. V2G) galima būtų panaudoti elektros tinklo dažniui reguliuoti. Teigiama, kad elektromobilių kaip energijos kaupiklių panaudojimas trumpam aktyviosios galios balansui palaikyti siekiant atkurti normalų dažni yra perspektyvi priemonè elektros energetikos sistemai, kurioje automatinio generacijos valdymo sistema nepajejgia suvaldyti galios poreikio ir pateikimo balanso. Aptariamos energijos kaupimo alternatyvų, pirmiausia superlaidaus magnetinio kaupimo ir ultrakondensatorių, galimybès. Nagrinejamas jungtinis elektromobilių darbo ị tinklą ir vèjo elektrinių generacijos modelis, kaip alternatyvi momentinès galios pateikimo ị tinklą priemoné, situacijoms, kai sistema patiria staigius trikdžius. MATLAB/Simulink priemonėmis modeliuojamas išmanus dažnio nuokrypių ir galios svyravimų tarpsisteminèse jungtyse mažinimas neraiškiosios logikos valdikliu, naudojančiu dalelių spiečiaus optimizavimo metodą. Pateikiami išsamūs modeliavimo rezultatai ir aptariama jų reikšmė galiai bei dažniui reguliuoti.

Raktažodžiai: automatinis generacijos valdymas, adaptyvioji dalelių spiečiaus optimizacija, elektromobilio darbas ị tinklą, trumpalaikè aktyvioji galia, vejjo generacija, neraiškiosios logikos valdiklis 